\title{
The Impacts of Collaborative Writing on EFL Students' Paragraph Writing Performance
}

\author{
Thao Thu Thi Nguyen, Hoang Yen Phuong \\ Can Tho University, Vietnam
}

\begin{abstract}
In Vietnam, writing is considered the most challenging skill by English as a Foreign Language (EFL)students. These students encounter various kinds of problems in their writing process, from generating ideas to revising their tasks. Previous studies reveal that collaborative writing could bringstudents numerous benefits regarding their writing performance. The present study was conducted to examinethe impacts of collaborative writing on EFL students' paragraph writing performance and investigate their attitudes toward using collaborative writing in learning English writing. This research followed a mixed-method design, which lasted 15 weeks and was conducted with the participants of 80 EFL tenth-grade students in a high school context. Three research instruments namely the writing tests (pre-and post-test), questionnaires, and semi-structured interviews were employed in this study. The findings showedan improvement in EFL students' paragraph writing performance after they had experienced collaborative writing. Moreover, the majority of EFL students also showed their highly positive attitudes towards using collaborative writing in learning English writing. Finally, the suggested pedagogical implications of using collaborative writing in learning English writing are hoped to contribute to the innovation of teaching writing in the context of high school in the Mekong Delta of Vietnam.
\end{abstract}

Keywords: paragraph writing, collaborative writing, EFL student' attitudes

\section{INTRODUCTION}

English plays an essential role in almost all the fields in the age of globalization. In the context of Vietnam, English has become a necessary means of communication in the age of international integration, and it is also an important language for communication in Vietnam. For English subject at high schools, writing in general and paragraph writing in particular, is one of the most difficult skills. Students usually felt difficult when developing and organizing ideas, using correct grammar and word choices, and applying correct writing mechanics. Thus, the number of students successful in writing is too small. Within that context, collaborative writing can be applied to help EFL students improve their writing performance and inspire their motivation in learning English. Furthermore, collaborative writing (CW) has been embraced to generate and support knowledge co-construction in education; facilitates deep learning and a communication channel in pedagogy that stimulates learner autonomy, creativity, and critical thinking (Cliff Hodges, 2002; Lowry, Curtis, and Michelle René Lowry, 2004). While the findings of previous research have shed some light on the effects of CW (Kim, 2020; Letters \& Examiners, 2016; Studies, International \& Centre, 2015; Shehadeh, 2011), EFL students' attitudes (Abahussain, 2020; Chen \& Yu, 2019; Ismail \& Lustyantie, 2020), little research has been conducted to investigate the impacts of CW on EFL students' paragraph writing performance in Vietnam in common and in the Mekong Delta in particular. This is a gap that needs to be fulfilled.

The study was conducted to examine the impacts of collaborative writing on EFL students' paragraph writing performanceand investigatetheir attitudes toward usingcollaborative writingin learning English writing.In relation to the research aims, this present study attempted to answer two questions:

1. What are the impacts of collaborative writing on EFL students' paragraph writingperformance?

2. What are students' attitudes toward using collaborative writingin learning English writing? 
DOI: $\underline{10.51386 / 25815946 / i j s m s-v 4 i 4 p 117}$

Volume: 4 Issue: 4

July to August 2021

https://www.ijsmsjournal.org

\section{LITERATURE REVIEW}

\subsection{Paragraph writing performance}

\subsubsection{Writing}

According to Sapkota (2013), writing has a function to present a language to convey some meaning so that the reader can grasp the information. Additionally, Weigle (2002) stated that there are several cognitive and meta cognitive activities like brainstorming, planning, outlining, organizing, drafting, and revising involved in writing making it a complicated skill to master. According to Uusen (2006), writing is a skill that integrates knowledge and many sub-skills. Two aspects should be considered by the writers. First, the writing process relates to pre-writing, drafting, revising, editing, and publishing (Fachrurrazy, 2011). Second, they have to accumulate micro and macro skills of writing, such as the ability to use word diction, grammar, and writing mechanics including the use of the capital letter, spelling, and punctuation (Brown \& Lee, 2015). Taking all of the above viewpoints into account, writing is regarded as a complicated process that involves an individual's effort to convey and make sense of ideas to the target audience. As a result, writing is essential in English language teaching and learning.

\subsubsection{Paragraph writing}

Paragraph writing has been defined as a combination of sentences, intended to explain, illustrate, prove, apply some truth, or to give a history of events during any definite portion of time, relation to anyone subject of thought (Duncan, 2007. p.111). Ives et al. (2011) stated that a paragraph is much more than a collection of connected sentences. It is a building block of essay development, and paragraph provide the structure needed to develop the thesis of a paper. Indeed, a paragraph is a "mini-essay," with its mini-thesis (the topic sentence), middle or body (the supporting details), and end or conclusion (the concluding sentence).

\subsubsection{Writing performance}

Writing performance is the demonstration of writing competence. Writing competence is a combination of knowledge making up effective writing. The knowledge can be seen as knowledge of content and context (the ability to fulfill the requirement of the task in terms of content in appropriate style and genres of using language), knowledge of language system (the ability of grammar and vocabulary), and knowledge of writing process (the ability to monitor the preparation for a writing task including outlining, drafting, revising and editing). As a result, to assess students' writing performance, teachers should assess writing texts focusing on the content, organization, vocabulary, language use, and mechanics Jacobs (1981, cited in Shehadeh 2011a).

\subsection{Collaborative writing}

According to Brooks and Swain (2008), collaborative writing (CW) may be defined as the joint production or the coauthoring of a text by two or more writers. Additionally, CW is strongly supported by a substantial research base in cooperative learning, which can be defined as "students working together in a group small enough that everyone can participate on collective tasks without the direct and immediate supervision of the teacher" (Cohen, 1994). The value of CW as a means to develop the linguistic and writing conventions of a second language has also been underpinned from a socio cultural perspective (Storch, 2005). Collaborative writing is a way to foster reflective thinking, especially if the learners are engaged in the act of explaining and defending their ideas to their peers (Liang, 2010).

Storch (2011) summarized the benefits of CW as follows. First, it fosters the development of cognitive processes and learning. This means that through the practice of $\mathrm{CW}$, students eventually become reflective thinkers who are more aware of the comprehension of their audience. Second, CW also fosters the process of producing language which includes lexical choices and grammatical forms. Al Ajmi and Ali (2014) further stated that CW is a means to develop second language students' linguistic and writing conventions. In order to achieve a good written product, members must go through the social process in which they must interact, coordinate, and negotiate to reach the common goal (Dobao \& Blum, 2013). Moreover, CW practice also increases students' motivation, self-esteem, and a greater sense of responsibility; therefore, all these qualities foster students to be better writers (Mulligan \& Garofalo, 2011). 
DOI: $10.51386 / 25815946 /$ ijsms-v4i4p117

Volume: 4 Issue: 4

July to August 2021

https://www.ijsmsjournal.org

Despite claimed benefit of $\mathrm{CW}$, some argue that the concept of $\mathrm{CW}$ is unfair and penalize highly proficient achievers who prefer working individually. These high achiever have to waste their time with disagreement management and accept a lower quality of writing contribute by all or most team member (Storch, 2013). The disadvantages of $\mathrm{CW}$ are put into five categories namely stress, time management, target language proficiency, conflict with personal learning styles and opinions, and fairness issues. Stress occurs when there is a conflict within the team members and especially when it cannot be resolved. Time management problems of the individual can also affect team time management and often lead to conflicts of both opinions and personal learning styles. All these conflicts, consequently, can lead to unfair work contribution.

\subsection{EFL students' attitudes towards collaborative writing}

Eagly and Chaiken (1993 cited in Schwarz and Bohner, 2001) stated that "an attitude is a psychological tendency that is expressed by evaluating a particular entity with some degree of favor or disfavor". Similarly, Krech and Crutchfield (1948 cited in Schwarz and Bohner, 2001) wrote that "An attitude can be defined as an enduring organization of motivational, emotional, perceptual, and cognitive processes with respect to some aspect of the individual world" (p. 152).

Recently, there were a few studies carried out to explore attitudes on CW. Gokce (2001) fulfilled a study to test learners' attitudes towards collaborative writing. The result indicated that negative attitude towards writing turned into positive ones after the collaborative writing. Hinkel (2011) conducted a study to investigate the students' attitudes towards $\mathrm{CW}$ in teaching and learning. The result indicated that most students perceived collaborative writing as beneficial, as it allowed them to develop their communication skills as well as produce a final written text of higher quality in terms of local and global aspects. In the same line, Abdel and Farrah (2011) conducted a study to scrutinize students' attitudes towards using collaborative writing. The results also reported that the students had positive attitudes towards collaborative learning. Alawaji (2020) implemented a study to investigate students' attitudes related to collaborative writing. The findings suggested that most of the participants express positive attitudes toward collaborative writing and consider it beneficial for improving different aspects of writing skills, second language proficiency, and confidence.

\section{METHODOLOGY}

In order to examine the impacts of collaborative writing on EFL students' paragraph writing performance and investigate their attitudes toward using collaborative writing in their learning English writing, a mixed-method design was employed in this study. According to Lichtman (2013), the mixed-method design is to combine both quantitative and qualitative methods in the study. In the first stage, a quasi-experimental design was used to measure the mean scores of EFL students' paragraph writing performance before (pretest) and again after (posttest) they had experienced collaborative writing on their learning English writing. The writing tests were taken and adapted from“ThựchànhTiếng Anh 10”, by ThúyLiên-Minh Thọ-BíchNgọc, 2016, NXB GiáodụcViệt Nam”. In the second stage, a descriptive study was designed with a questionnaire and semi-structured interviews to determine EFL students' attitudes towards using collaborative writing in learning English writing and get a deeper understanding of whether collaborative writing helps EFL students improve their paragraph writing performance.

For the quantitative approach, the questionnaire was adopted and adapted from three main sources by Abdel \& Farrah (2011), Albesher (2012), Coffin (2020), modified and developed by the researcher based on the theoretical frame work of attitudes constructed by Eagly and Chaiken (1998). The questionnaire was divided into two main sections. The first section was composed of questions asking for the participants' background information related to their name and gender. The second section, focused on thirty-five items, aimed at gaining insights into students' attitudes toward using collaborative writing on their English writing. All the items in this section were categorized into 5 clusters including EFL students' enjoyment of writing activities using collaborative writing, the impacts of using collaborative writing in learning English writing, the challenges of using collaborative writing in learning English writing, EFL students' learning outcomes of using collaborative writing in learning English writing andthe future demands of using collaborative writing for learning to write English.To complement the qualitative data, six participants ( 3 with more improvement and 3 with less improvement) were invited to take part in semistructured interviews based on their mean scores before and after treatment. 
DOI: $10.51386 / 25815946 /$ ijsms-v4i4p117

Volume: 4 Issue: 4

July to August 2021

https://www.ijsmsjournal.org

80 participants of Grade 10 from a high school where the researcher is teaching, participated in this study. The participants aged 16 and consisted of $37(46.2 \%)$ males and $43(53.8 \%)$ females. These participants were assumed to be similar in terms of proficiency and background knowledge. They were divided into two groups as an experimental group including 40 students and a control group 40.

All of the instruments were read and checked by the supervisor and then piloted to ensure the reliability. Thirty-five EFL students were chosen to participate in the pilot in the first week of the study. The reliability score of the questionnaire was $\alpha=.936$ indicated the high reliabilityfor data collection.Simultaneously, the responses and opinions received from the pilot interview participants permitted for the clarification of the questions, the length of time spent in the process, and adjustments to the content and sequence in preparation for the actual interviews.

The data collected and analyzed by using the computer software Statistical Package for the Social Sciences (SPSS) version 20. The interview responses were recorded, transcribed, coded, and then translated into English. Analysis of the interviews was based on identifying the themes (Eagly and Chaiken, 1998) emerged through the interview process.

\section{FINDINGS}

After analyzing the data from the writing tests, questionnaire, and interviews, an improvement of EFL students' paragraph writing performance through using collaborative writing and EFL students' high positive attitudes towards using collaborative writing in learning English writing were found.

\subsection{Students' paragraph writing performance}

EFL students' paragraph writing performance between the two groups beforeandafter the intervention was analyzed by the Descriptive Statistic Test and Independent Sample T Test. Firstly, Descriptive Statistics Test was conducted to examine minimum score (Min), maximum score (Max), mean score (M) and standard deviation (SD) of pretest and posttest of the two groups. The results are demonstrated in Table 4.1below.

Table 4.1: EFL students' paragraph writing performance between the two groups

\begin{tabular}{ccccccc}
\hline Writing tests & Groups & N & Min & Max & M & SD \\
\hline \multirow{2}{*}{ Pretest } & Experimental & 40 & 3.40 & 6.50 & 4.89 & .72 \\
& Control & 40 & 3.35 & 6.20 & 4.98 & .79 \\
\hline \multirow{2}{*}{ Posttest } & Experimental & 40 & 4.35 & 8.45 & 6.17 & .94 \\
& Control & 40 & 3.65 & 6.70 & 5.34 & .91 \\
\hline
\end{tabular}

As can be seen in Table 4.1, the mean score of EFL students' paragraph writing performance in the control group $(M=4.98, S D=.79)$ was a littlebit higher than the mean score of EFL students' paragraph writing performancein the experimental group $(M=4.89, S D=.72)$ before the intervention. Secondly, Independent Sample T Test was run to test whether there was a significant difference of EFL students' paragraph writing performance inthe pretest between the experimental group $(M=4.89)$ and the control group $(M=4.98)$. The resultsindicated that the difference ofEFL students' paragraph writing performance in the pretest between the two groups was not significant $(t=-.550, d f=78, p=.584)$. This means that EFL students' paragraph writing performance in the pretest of two groups was the same. The two groups were distributed homogenously before the intervention.

Moreover, Table 4.1 also revealed that EFL students' paragraph writing performance between the two groups was different after the intervention. After eight weeks of the intervention, the mean score of EFL students' paragraph writing performance inthe experimental group $(M=6.17, S D=.94)$ was higher than the mean score of EFL students' paragraph writing performance in the control group $(M=5.34, S D=.91)$. Independent Sample T Test was conducted to investigate whether there was a significant difference of EFL students' paragraph writing performance inthe posttest between the experimental group $(M=6.17)$ and the control group $(M=5.34)$. The results reported that the difference of EFL students' paragraph writing performance in the posttest between the two groups wassignificant $(t=4.055, d f=78, p=.00)$. Hence, EFL students' paragraph writing performance in the posttest of the two groups was different after the intervention.Figure 4.1 below presented theprogress of both control group and experimental group. 
DOI: $10.51386 / 25815946 /$ ijsms-v4i4p117

Volume: 4 Issue: 4

July to August 2021

https://www.ijsmsjournal.org

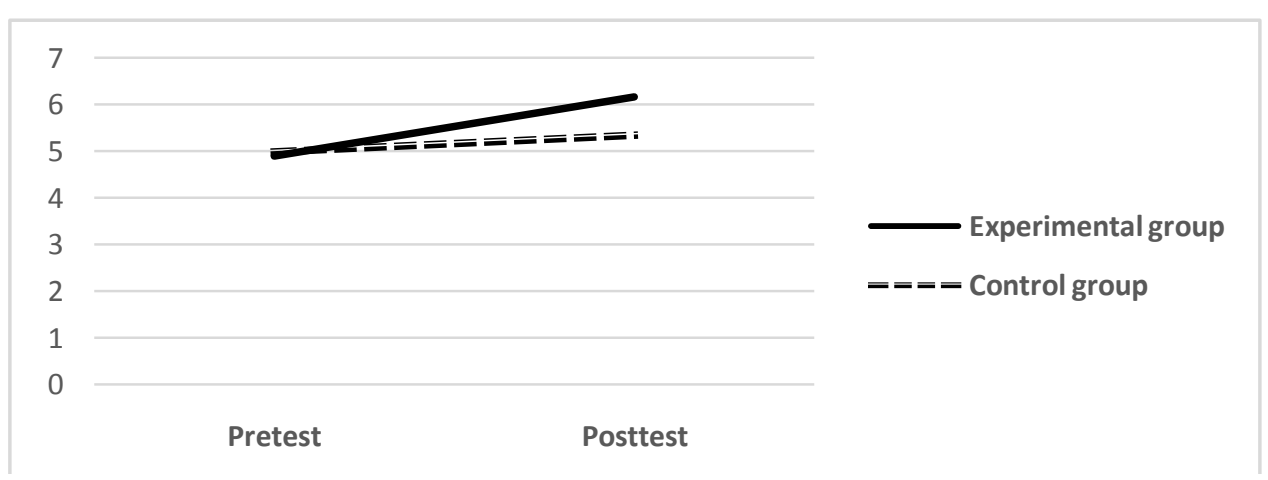

Figure 4.1: EFL students' paragraph writing performance before and after the study between the two groups

It can be clearly seen from figure 4.1 that EFL students' paragraph writing performance before the study performed a noticeably small gap between experimental group $(M=4.89)$ and control group $(M=4.98)$ whereas after the study performed an improvement of EFL students' paragraph writing performance between the two groups. It could not be denied that the posttest's result of the experimental group $(M=6.17)$ was higher thanthe control one's $(M=5.34)$. As a result, students learned better with the intervention. This inferred that a high improvement of EFL students' paragraph writing performance through experiencing collaborative writing.

EFL students' paragraph writing performanceon the specific components within the two groups beforeandafter the study was analyzed by the Descriptive Statistic Testand Paired - Sample T Test. First, Descriptive Statistics Test was run to test the mean score (M) of pretest and posttest withinthe two groups. The results are demonstrated in Table 4.2 below.

Table 4.2: EFL students' paragraph writing performance on five specific components within the two groups

\begin{tabular}{|c|c|c|c|c|c|c|c|}
\hline Groups & $\begin{array}{c}\text { Writing } \\
\text { tests }\end{array}$ & $\mathbf{N}$ & Content & Organization & Vocabulary & $\begin{array}{c}\text { Language } \\
\text { use }\end{array}$ & Mechanics \\
\hline \multirow{2}{*}{ Experimental } & Pretest & 40 & 1.49 & 1.11 & 1.08 & .96 & .26 \\
\hline & Posttest & 40 & 1.89 & 1.38 & 1.32 & 1.23 & .36 \\
\hline \multirow{2}{*}{ Control } & Pretest & 40 & 1.46 & 1.11 & 1.12 & 1.03 & .27 \\
\hline & Posttest & 40 & 1.62 & 1.17 & 1.17 & 1.06 & .33 \\
\hline
\end{tabular}

Next, the paired - sample ttestwas calculated to compare whether the mean score of the five specific components within experimental group and control group before and after the study are different. After intervention program, EFL students' paragraph writing performance of the experimental group in terms of content, organization, vocabulary, language use and mechanics was statistically different from before the study $(t=5.14, p=.00 ; t=6.21$, $p=.00 ; t=6.05, p=.00 ; t=6.71, p=.00 ; t=6.64, p=.00)$. The results in Figure 4.2 indicated that EFL students improved their paragraph writing performance in terms of content, organization, vocabulary, language use and mechanics through using collaborative writing. It was also seen that EFL students made big progress in five specific components after the study, but language use saw minor improvement. 
DOI: $10.51386 / 25815946 /$ ijsms-v4i4p117

Volume: 4 Issue: 4

July to August 2021

https://www.ijsmsjournal.org

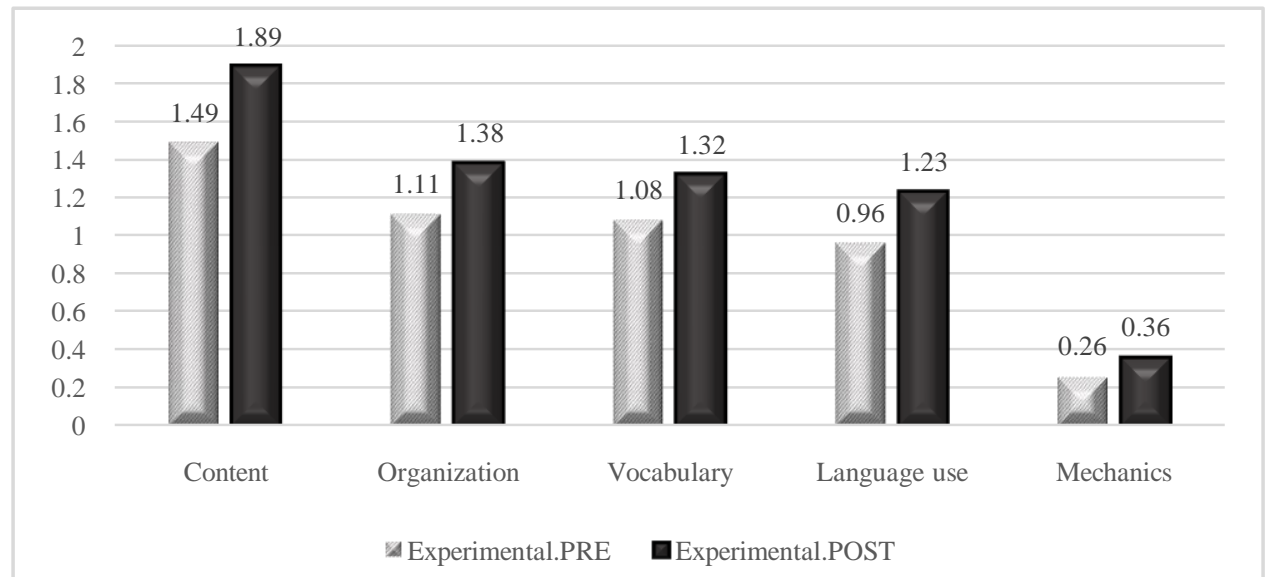

Figure 4.2: Students' paragraph writing performance on specific components of experimental group

For the control group, the results indicated that EFL students' paragraph writing performance in terms of content, organization, vocabulary, language use and mechanics was statistically different from before the study ( $t=4.06, p=.00 ; t=4.61, p=.00 ; t=3.43, p=.00 ; t=2.48, p=.02 ; t=5.31, p=.00)$. The results in Figure 4.3 indicated that EFL students also improved their paragraph writing performance in terms of content, organization, vocabulary, language use and mechanics. In summary, although EFL students' paragraph writing performance in terms of five specific components after the study was higher than that before the study, only content saw big progress.

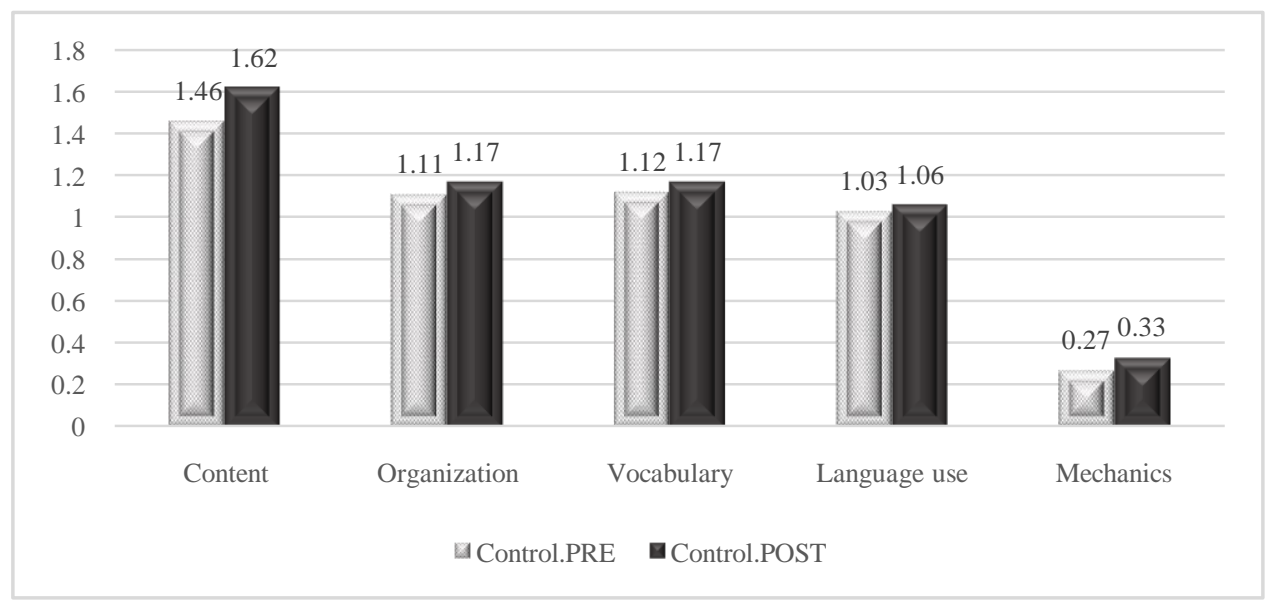

Figure 4.3: EFL students' paragraph writing performance on specific components of control group

\subsection{Students' attitudes toward collaborative writing on their writing performance}

\subsubsection{EFL students' enjoyment of writing activities using collaborative writing}

A great number of EFL students showed their enjoyment of writing activities using collaborative writing. The finding was supported by both quantitative and qualitative data. The results of the first cluster of the questionnaire with 8 items were shown in Table 4.3 below. 
DOI: $\underline{10.51386 / 25815946 / i j s m s-v 4 i 4 p 117}$

Volume: 4 Issue: 4

July to August 2021

https://www.ijsmsjournal.org

Table 4.3: EFL students' enjoyment of writing activities using collaborative writing.

\begin{tabular}{|c|c|c|c|c|c|}
\hline & Items & $\begin{array}{l}\text { Me } \\
\text { an }\end{array}$ & $\begin{array}{l}\text { SD \& D } \\
(\%)\end{array}$ & $\begin{array}{c}\text { Neutral } \\
(\%)\end{array}$ & $\begin{array}{c}\mathbf{A} \& \mathbf{S A} \\
(\%)\end{array}$ \\
\hline 1 & Collaborative writing activities are interesting. & 3.55 & 10.0 & 27.5 & 62.5 \\
\hline 2 & I enjoy working with my classmates in using collaborative writing. & 4.00 & 0.0 & 22.5 & 77.5 \\
\hline 3 & I enjoy learning English writing through using collaborative writing. & 4.30 & 0.0 & 7.5 & 92.5 \\
\hline 4 & $\begin{array}{l}\text { I am more engaged in English writing activities that use collaborative } \\
\text { writing. }\end{array}$ & 3.88 & 2.5 & 27.5 & 70.0 \\
\hline 5 & $\begin{array}{l}\text { Using collaborative writing increases my interest in learning to write } \\
\text { English. }\end{array}$ & 3.95 & 0.0 & 25.0 & 75.0 \\
\hline 6 & $\begin{array}{l}\text { I prefer editing and proofreading my writing in a group rather than } \\
\text { individually. }\end{array}$ & 3.50 & 10.0 & 30.0 & 60.0 \\
\hline 7 & $\begin{array}{l}\text { I find it interesting to practice and learn writing skills through using } \\
\text { collaborative writing. }\end{array}$ & 3.98 & 2.5 & 22.5 & 75.0 \\
\hline 8 & $\begin{array}{l}\text { Practicing English writing using collaborative writing is more interesting } \\
\text { than doing it individually. }\end{array}$ & 4.15 & 0.0 & 20.0 & 80.0 \\
\hline
\end{tabular}

* N=60; SD \&D: Strongly disagree \& Disagree; A \& SA: Agree \& Strongly agree

The results in Table 4.3 indicated that most of the participants positively responded to these items. Remarkably, most of participants $(n=40)$ like working with their classmates in using collaborative writing $(M=4.00)$, learning English writing through using collaborative writing $(M=4.30)$, using collaborative writing to increase their interest in learning to write $\operatorname{English}(M=3.95)$ and practicing English writing using collaborative writing $(M=4.15)$. It can clearly be seen on Item $2,3,5$ and 8 . However, only $2.5 \%$ of the participants did not like using collaborative writing in English writing activities $(M=3.88)$, and learning writing skills through using collaborative writing $(M=3.98)$ on the proof of Item 4 and 7. In addition, a small number of the participants showed their disagreement on Item 1, 6 "Collaborative writing activities are interesting" (10.0\% disagree; $M=3.88)$ and editing, proofreading their writing in a group $(10.0 \%$ disagree; $M=3.98)$. In brief, the results indicated the students showed very low disagreement on the activities in which collaborative writing was integrated into learning to write English.

The data from the interviews also supported these findings. Practicing paragraph English writing using collaborative writing is found helpful. Most of students like using collaborative writing to write paragraphs in English. They expressed that they enjoy using collaborative writing in the process of paragraph English writing. EFL students also stated that collaborative writing is a very important and necessary activity. Especially, collaborative writing is one of the important activities in the English paragraph writing classes. The students reported,

I like using collaborative writing to learn English paragraph writing because it is very helpful to me. (Student A)

I love using collaborative writing to write paragraphs in English. (Student B)

I quite like using collaborative writing to write paragraphs in English. (Student C)

I like using collaborative writing to learn paragraph English writing. (Student D)

I feel that I really enjoy using collaborative writing in the process of writing English paragraphs. (Student F)

From what has been discussed, it could be seen that EFL students highly perceive their enjoyment of using collaborative writing in learning English writing. 
DOI: $\underline{10.51386 / 25815946 / i j s m s-v 4 i 4 p 117}$

Volume: 4 Issue: 4

July to August 2021

https://www.ijsmsjournal.org

\subsubsection{The impacts of using collaborative writing in learning English writing}

The quantitative data in conjunction with the qualitative data leaked that EFL students well perceived the positive impacts of using collaborative writing in learning English writing. The results of the second cluster of the questionnaire consisting of 11 items are shown in Table 4.4 below.

\begin{tabular}{|c|c|c|c|c|c|}
\hline & Items & Mean & $\begin{array}{l}\text { SD \& D } \\
(\%)\end{array}$ & $\begin{array}{c}\text { Neutral } \\
(\%)\end{array}$ & $\underset{(\%)}{\mathbf{A} \& \text { SA }}$ \\
\hline 9 & $\begin{array}{l}\text { Collaborative writing stimulates my critical thinking skill in English } \\
\text { writing practices. }\end{array}$ & 4.13 & 5.0 & 10.0 & 85.0 \\
\hline 10 & $\begin{array}{l}\text { Practicing English writing using collaborative writing makes me develop } \\
\text { my problem-solving skill. }\end{array}$ & 4.15 & 2.5 & 15.0 & 82.5 \\
\hline 11 & $\begin{array}{l}\text { Collaborative writing helps me receive useful feedback in learning } \\
\text { English writing. }\end{array}$ & 3.98 & 0.0 & 25.0 & 75.0 \\
\hline 12 & $\begin{array}{l}\text { Practicing English writing using collaborative writing has fostered the } \\
\text { exchange of knowledge, information and experience. }\end{array}$ & 4.10 & 5.0 & 10.0 & 85.0 \\
\hline 13 & $\begin{array}{l}\text { Practicing English writing using collaborative writing makes me have a } \\
\text { greater responsibility for myself and the group. }\end{array}$ & 4.03 & 5.0 & 7.5 & 87.5 \\
\hline 14 & $\begin{array}{l}\text { Practicing English writing using collaborative writing enables me to help } \\
\text { weaker members in the group. }\end{array}$ & 3.83 & 5.0 & 30.0 & 65.0 \\
\hline 15 & $\begin{array}{l}\text { Collaborative writing is a good strategy that helps me to write my } \\
\text { English paragraph effectively. }\end{array}$ & 4.15 & 5.0 & 10.0 & 85.5 \\
\hline 16 & $\begin{array}{l}\text { In the pre-writing stage, planning a topic with friends is much better than } \\
\text { doing it individually. }\end{array}$ & 4.30 & 0.0 & 15.0 & 85.5 \\
\hline 17 & $\begin{array}{l}\text { In the pre-writing stage, making an outline and writing down ideas with } \\
\text { classmates are good methods. }\end{array}$ & 4.25 & 0.0 & 17.5 & 82.5 \\
\hline 18 & $\begin{array}{l}\text { Practicing English writing using collaborative writing helps me revise } \\
\text { my writing effectively. }\end{array}$ & 4.28 & 0.0 & 12.5 & 87.5 \\
\hline 19 & $\begin{array}{l}\text { When practicing English writing using collaborative writing, I spend } \\
\text { more time checking spelling, punctuation and grammar than doing it } \\
\text { alone. }\end{array}$ & 3.88 & 0.0 & 32.5 & 67.5 \\
\hline
\end{tabular}

\section{* N=60; SD \&D: Strongly disagree \& Disagree; A \& SA: Agree \& Strongly agree}

From the data in Table 4.4, more than $82.5 \%$ of the students believed that collaborative writing stimulates their critical thinking skill in English writing practices $(M=4.13)$. They stated that practicing English writing using collaborative writing helps them develop their problem-solving skill $(M=4.15)$, have a greater responsibility for themselves and the group $(M=4.30)$, write my English paragraph effectively $(M=4.05)$ and revise my writing effectively $(M=4.28)$. Also, they believed that practicing English writing using collaborative writing has fostered the exchange of knowledge, information and experience. $(M=4.10)$. It can clearly be seen on Items $9,10,13,15,18$ and 12. In Item 16 and 17, students showed that planning a topic with friends is much better than doing it individually as well as making an outline and writing down ideas with classmates are good methods in the pre-writing stage $(M=4.30$ and 4.25$)$. The majority of the students believed that when practicing English writing using collaborative writing, they spend more time checking spelling, punctuation and grammar than doing it alone $167.5 \%$ agree; $M=$ 3.88) on the evidence of Item 19. Additionally, in Item 11, third-four of the students expressed that collaborative writing helps them receive useful feedback in learning English writing $(M=3.98)$. Strikingly, in Item14, only 5.0\% of the students did not consider that practicing English writing using collaborative writing enables them to help weaker members in the $\operatorname{group}(M=3.83)$. In summary, the results showed that EFL students well identified the positive impacts of using collaborative writing in learning to write English.

Additionally, these findings were strongly supported by interview data. The improvement in EFL students' writing quality was found out.Most of students indicated that collaborative writing aids the development of rich ideas, more convincing factual evidence, and logical reasoning between concepts, and consistency in their paragraphs. The students expressed that they could share their ideas with friends and obtain many ideas from their friends to boost their writing better. Thus, EFL students have a chance to enhance their vocabulary and language use through using collaborative writing. They expressed, 
DOI: $10.51386 / 25815946 /$ ijsms-v4i4p117

Volume: 4 Issue: 4

July to August 2021

https://www.ijsmsjournal.org

Collaborative writing helps my paragraphs generate rich ideas, more convincible factual evidence and logical arguments between ideas, connections and consistency.(Student A)

After finishing paragraphs, they will be of higher quality than the traditional way we used to. (Student A)

I have more time to create my writings better and at the same time, I can also learn how to think about finding your ideas.

(Student E)

Collaborative writing helps students understand how to use grammar and vocabulary in the most appropriate cases and helps students make English writing easier. (Student D)

In conclusion, from both quantitative and qualitative data, it could be seen that the positive impacts of using collaborative writing in learning English writing were well responded by EFL students.

\subsubsection{The challenges of using collaborative writing in learning English writing}

Both quantitative and qualitative data revealed the challenges of using collaborative writing in learning English writing. The results of the third cluster of the questionnaire with 4 items were shown in Table 4.5 below.

Table 4.5: The challenges of using collaborative writing in learning English writing

\begin{tabular}{|c|c|c|c|c|c|}
\hline & Items & Mean & $\begin{array}{l}\text { SD \& D } \\
(\%)\end{array}$ & $\begin{array}{l}\text { Neutral } \\
(\%)\end{array}$ & $\begin{array}{l}\mathbf{A} \text { \& SA } \\
(\%)\end{array}$ \\
\hline 20 & $\begin{array}{l}\text { When using collaborative writing, all group members contributed unequally } \\
\text { to their writing. }\end{array}$ & 3.95 & 2.5 & 27.5 & 70.0 \\
\hline 21 & $\begin{array}{l}\text { There are conflicts with group members as using collaborative writing in } \\
\text { learning English writing. }\end{array}$ & 4.00 & 7.5 & 12.5 & 80.0 \\
\hline 22 & $\begin{array}{l}\text { Using collaborative writing in learning English writing is a waste of time as } \\
\text { I keep explaining things to others. }\end{array}$ & 3.83 & 7.5 & 20.0 & 72.5 \\
\hline 23 & $\begin{array}{l}\text { When using collaborative writing, I spend more time generating ideas, } \\
\text { planning and revising my English writing than doing it alone. }\end{array}$ & 3.98 & 2.5 & 20.0 & 77.5 \\
\hline
\end{tabular}

* N=60; SD \&D: Strongly disagree \& Disagree; A \& SA: Agree \& Strongly agree

As presented in Table 4.5, Items 21 received the most positive responses, which indicated that there are conflicts with group members as using collaborative writing in learning English writing (80.0\% agree; M= 4.00). Noticeably, only 1 out of 40 participants disagreed on Items 20 and 23 (2.5\% disagree). The majority of the students perceived that using collaborative writing in learning English writing is a waste of time as they keep explaining things to others $(72.5 \%$ agree; $M=3.83)$. In conclusion, the results unveiled a large number of the students' agreement on the challenges of using collaborative writing in learning English writing.

EFL students divulged that collaborative writing causes conflicts among friends. They also highlighted that collaborative writing leads to disagreements and arguments among group members, which affects the whole progress of the writings. They also stated that when collaborativewriting, there will be a case of abdication of responsibility. They articulated,

Collaborative writing causes conflicts among friends. (Student A)

Collaborative writing can lead to arguments, which can cause disunity within the groups. This argument can take a long time to agree. (Student B)

Whencollaborativewriting, there will be a case of abdication of responsibility. (Student F)

Altogether, it could be concluded that EFL students' attitudes towards challenges of using collaborative writing were tested from both quantitative and qualitative data. 
DOI: $\underline{10.51386 / 25815946 / i j s m s-v 4 i 4 p 117}$

Volume: 4 Issue: 4

July to August 2021

https://www.ijsmsjournal.org

\subsubsection{EFL students' learning outcomes of using collaborative writing in learning English writing}

The quantitative data disclosed EFL students' attitudes towardstheir learning outcomes through using collaborative writing in learning English writing. The results of the fourth cluster with 8 items were shown in Table 4.6below.

Table 4.6: EFL students' learning outcomes of using collaborative writing in learning English writing

\begin{tabular}{|c|c|c|c|c|c|}
\hline & Items & Mean & $\begin{array}{l}\text { SD \& D } \\
(\%)\end{array}$ & $\begin{array}{c}\text { Neutral } \\
(\%)\end{array}$ & $\begin{array}{l}\text { A \& SA } \\
(\%)\end{array}$ \\
\hline 24 & Collaborative writing enhances my communication skills. & 4.05 & 0.0 & 17.5 & 82.5 \\
\hline 25 & I learn how to solve problems after using collaborative writing. & 4.13 & 0.0 & 17.5 & 82.5 \\
\hline 26 & I learn how to manage conflicts after using collaborative writing. & 3.83 & 7.5 & 25.0 & 67.5 \\
\hline 27 & I learn how to work with others after using collaborative writing. & 4.20 & 0.0 & 20.0 & 80.0 \\
\hline 28 & Collaborative writing improves my paragraph writing performance. & 4.08 & 0.0 & 30.0 & 70.0 \\
\hline 29 & $\begin{array}{l}\text { Collaborative writing helps me to participate actively in the learning } \\
\text { process. }\end{array}$ & 3.95 & 0.0 & 27.5 & 72.5 \\
\hline 30 & $\begin{array}{l}\text { Collaborative writing helps me get better scores in my paragraph writing } \\
\text { exams. }\end{array}$ & 3.95 & 0.0 & 30.0 & 70.0 \\
\hline 31 & $\begin{array}{l}\text { I am more confident to work with other classmates after using collaborative } \\
\text { writing. }\end{array}$ & 4.08 & 0.0 & 22.5 & 77.5 \\
\hline
\end{tabular}

* N=60; SD \&D: Strongly disagree \& Disagree; A \& SA: Agree \& Strongly agree

From the data in Table 4.6, more than $80.0 \%$ of the students believed that collaborative writing enhances their communication skills (Item 24, M=4.05), learn how to solve problems after using collaborative writing (Item $25, M=4.13$ ) and learn how to work with others after using collaborative writing (Item 27, $M=4.20$ ). They stated that collaborative writing helps them get better scores in their paragraph writing exams (Item 30, $M=3.95$ ) and improve their paragraph writing performance (Item 28, $M=4.08$ ). Also, they believed that they feel more confident to work with other classmates after using collaborative writing $(M=4.08)$ and help them to participate actively in the learning process $(M=3.95)$. It can clearly be seen on Item 31 and 29 . Strikingly, in Item 26, only $7.5 \%$ of the students did not learn how to manage conflicts after using collaborative writing $(M=3.83)$. In summary, the results showed that EFL students well identified their learning outcomes through using collaborative writing in learning English writing.

The results from the interviews showed that practicing English writing using collaborative writing aids EFL students not only improve their writing skills but also build up their confidence. EFL students expressed that thank to collaborative writing, they also achieve communication skills as they were able to share their ideas and communicate with their friends. EFL students enhance their critical thinking through learning new ways thinking from their friends. They reported,

Collaborative writing trains us with confidence, communication skills, and improves our writing skills with the help of friends.(Student B)

Collaborative writing helps students improve their writing skills.(Student D)

Collaborative writing helps us develop critical thinking. (Student A)

Collaborative writing increases teamwork ability.(Student F)

In brief, the finding from both quantitative and qualitative data pinpointed the proof of the improvement of EFL students' learning outcomes through collaborative writing. 
DOI: $\underline{10.51386 / 25815946 / i j s m s-v 4 i 4 p 117}$

Volume: 4 Issue: 4

July to August 2021

https://www.ijsmsjournal.org

\subsubsection{The future demands of using collaborative writing for learning to write English.}

EFL students' high expectations of using collaborative writing in learning to write English was explored form both questionnaire and interview data. The results of the fifth cluster with 4 items were displayed in Table4.7.

Table 4.7: The future demands of using collaborative writing for learning to write English

\begin{tabular}{llcccc}
\hline & \multicolumn{1}{c}{ Items } & Mean & $\begin{array}{c}\text { SD \& D } \\
(\boldsymbol{\%})\end{array}$ & $\begin{array}{c}\text { Neutral } \\
(\mathbf{\%})\end{array}$ & $\begin{array}{c}\text { A \& SA } \\
(\mathbf{\%})\end{array}$ \\
\hline 32 & Collaborative writing should be encouraged and continued. & 4.18 & 0.0 & 22.5 & 77.5 \\
\hline 33 & I would like to study English writing using collaborative writing. & 4.18 & 0.0 & 15.0 & 85.0 \\
\hline 34 & $\begin{array}{l}\text { I hope collaborative writing will enable me to study English writing more } \\
\text { efficiently. }\end{array}$ & 3.98 & 5.0 & 12.5 & 82.5 \\
\hline 35 & $\begin{array}{l}\text { I hope I get the opportunities to use collaborative writing for English } \\
\text { writing in the future. }\end{array}$ & 4.08 & 0.0 & 17.5 & 82.5 \\
\hline
\end{tabular}

* N=60; SD \&D: Strongly disagree \& Disagree; A \& SA: Agree \& Strongly agree

From the data in Table 4.7, 85\% of the participants expected to study English writing using collaborative writing $(M=4.18)$. Furthermore, they stated that collaborative writing should be encouraged and continued $(77.5 \%$ agree, $M=4.18$ ). Also, they hoped they got the opportunities to use collaborative writing for English writing in the future $(82.5 \%$ agree, $M=4.08)$. On the contrary, only $5.0 \%$ of the students did not hope that collaborative writing will enable them to study English writing more efficiently $(M=3.98)$. The results reported those EFL students' high expectations of using collaborative writing in learning to write English.

The findings from the interviews support the results of the questionnaire that the participants hope that collaborative writing will be expanded and replicated not only in the English pilot classes but also in other ones to assist EFL students improve their English writing abilities and increase their affection among friends. Also, they would like to continue using collaborative writing for learning to write English in the future because they aspire to discuss with their friends and improve their writing skills. They expressed,

I hope that collaborative writing will be expanded and replicated not only in the pilot classes but also in all other classes.(Student A)

I hope that using collaborative writing will be used more widely in my learning processes because it has many benefits as I mentioned.(Student F)

To me, I would like to continue using collaborative writing in the future.(Student B)

I would like to continue using collaborative writing to learn English paragraph writing.(Student D)

All in all, EFL students' high demands of practicing English writing through using collaborative writing in the future were found out from both quantitative and qualitative data.

\section{DISCUSSION}

From the results of the writing tests, questionnaire and interview data, it is underlined that collaborative writing can help EFL students improve their paragraph writing performance and students responded positively to the use of collaborative writing in learning English writing. The following section discusses the findings from this study in the relation to the research question.

Research question 1: What are the impacts of collaborative writing on EFL students' paragraph writing performance?

The findings from the writing tests, it is underlined that collaborative writing can help EFL students improve their paragraph writing performance. This finding is in line with the results of the previous studies (Kim, 2020; Letters \& Examiners, 2016; Studies, International \& Centre, 2015; Shehadeh, 2011). These authors stated that collaborative writing engages students to enhance content generation and organization; enrich vocabulary and language use; upgrade mechanics and the development of second language proficiency to improve EFL students' writing performance. 
DOI: $10.51386 / 25815946 /$ ijsms-v4i4p117

Volume: 4 Issue: 4

July to August 2021

https://www.ijsmsjournal.org

\section{Research question 2: What are students' attitudes toward using collaborative writing in learning English writing?}

With respect to EFL students' attitudes towards using collaborative writing in learning English writing, the questionnaire revealed that collaborative writing also helps EFL students achieve their knowledge co-construction, autonomy, creativity, communication skill, problem-solving skill and critical thinking. The findings are consistent with the results of previous studies(Cliff Hodges, 2002; Lowry, Curtis, and Michelle René Lowry, 2004; Shehadeh, 2011). In the same vein, EFL students believed that practicing English writing by using collaborative writing can make them interact, coordinate, and negotiate to reach the common goal. This is supported in the literature (Dobao \& Blum, 2013). Moreover, collaborative writing practice also increases students' motivation, self-esteem, and a greater sense of responsibility; therefore,all these qualities foster students to be better writers, which mentioned in another study by Mulligan and Garofalo (2011).

Moreover, the findings from the interview showed that EFL students' high positive attitudes towards using collaborative writing in learning English writing were found. EFL students stated that they find collaborative writing beneficial for improving different aspects of writing skills, second language proficiency, and communication skillsand confidence. The findings are proposed in the literature (Alawaji, 2020; Hinkel, 2011; Shehadeh, 2011). Moreover, the students reported that collaborative writing makes learning English writing more helpful and creative for improving writing, providing the opportunity to pool ideas, having positive emotional and social effects as well as creating a pleasant learning classroom atmosphere. These findings also parallel with the results of the prior studies (Abahussain, 2020; Chen \& Yu, 2019; Ismail \& Lustyantie, 2020).

Altogether, it could be concluded that after EFL students had experienced collaborative writing for learning to write English, an improvement in EFL students' paragraph English writing and positive view points towards using collaborative writing in learning English writing were scrutinized.

\section{CONCLUSION}

The present study was conducted to examine the impacts of collaborative writing on EFL students' paragraph writing performance and investigate their attitudes towards using collaborative writing in learning English writing. The findings from the writing tests first showed an improvement in EFL students' paragraph writing performance after they had experienced collaborative writing. Regarding EFL students' attitudes, the data from the questionnaire and interviews revealed that EFL students hold high positive attitudes towards using collaborative writing in learning English writing. In light of these findings, some pedagogical implications are drawn.

For teachers, the understanding of the impacts of collaborative writing on students' paragraph writing performance will assist teachers have a better view of using collaborative writing to teach English writing, make the right decisions on applying the teaching methods in the writing classroom, improve their writing programs and employ effective teaching strategies to further support their students' paragraph writing development. Therefore, EFL teachers should be aware of the supportive conditions that are necessary so that students can practice writing more effectively. In other words, teachers should give students maximum opportunities to practice English writing. One of the effective ways to do this is that should introduce collaborative writing into the classrooms for the students to have more English writing practice and experience English writing learning in a friendly environment, which increases the students' intrinsic motivation to learn English writing.

For students, this research is hoped to help them find out an effective strategy to improve their paragraph writing performance and inspire their motivation in learning English writing. Indeed, the findings of the present study showed EFL students' self-reliance and enjoyment when practicing writing English using collaborative writing. It is recommended that the students who have low English skills, shyness, and the lack of confidence should attend the classes in which collaborative writing isused to enhance their writing performance. It is suggested that collaborative writing should be used to practice English writing by the students since the use of collaborative writing can promote the students' confidence and communication skills. 
DOI: $10.51386 / 25815946 /$ ijsms-v4i4p117

Volume: 4 Issue: 4

July to August 2021

https://www.ijsmsjournal.org

\section{About the Authors}

ThaoThuThi Nguyenis currently an MA student at Can ThoUniversity, Vietnam.Her research interests include writing skills and strategies, and teaching methodology. She is also keen on improving the learning experience and applying innovative approaches for EFL students.

Hoang Yen Phuongis currently an Associate Professor at the School of Foreign Languages, Can Tho University, Vietnam.She carries studies on language teaching approaches, students' learning autonomy, self-regulated learning strategies and teachers' professional development. She published articles in different journals and is the editor of one book on formative assessment in language teaching.

\section{References}

[1] Abahussain, M. O. (2020). Investigating EFL Learners' Perceptions of Collaborative Writing. International Journal of English Linguistics, 10(3), 32.

[2] Abdel, M., \& Farrah, H. (2011). Attitudes Towards Collaborative Writing Among English Majors in Hebron University Dr. Mohammed Abdel Hakim Farrah English Department, Faculty of Arts Hebron University, Palestine. 2(4), 136-170.

[3] Al Ajmi, A. A. S., \& Ali, H. I. H. (2014). Collaborative writing in group assignments in an EFL/ESL classroom. English Linguistics Research,3(2), 1-17.

[4] Alawaji, N. N. M. (2020). Students' Perceptions of Collaborative Summary Writing. Theory and Practice in Language Studies, 10(6), 700 .

[5] Albesher, K. B. (2012). Developing the writing skills of ESL students through the collaborative learning strategy. Thesis Submitted for the Degree of Doctor of Philosophy (Integrated ) in Education and Applied Linguistics School of Education, School of(August), 1-279.

[6] Brooks, L., \& Swain, M. (2008). Languaging in collaborative writing: Creation of and response to expertise. In Multiple Perspectives on Interaction: Second Language Research in Honor of Susan M. Gass.

[7] Brown, H. D., \& Lee, H. (2015). Teaching principles. P. Ed Australia.

[8] Chen, Wenting, and Shulin Yu. 2019. "Implementing Collaborative Writing in Teacher-Centered Classroom Contexts: Student Beliefs and Perceptions." Language Awareness 28(4):247-67.

[9] Cliff Hodges, G. (2002). Learning through collaborative writing. Reading, 36(1), 4-10.

[10] Coffin, P. (2020). Implementing collaborative writing in EFL classrooms: Teachers and students' perspectives. LEARN Journal: Language Education and Acquisition Research Network, 13(1), 178-194.

[11] Cohen, E. G. (1994). Restructuring the classroom: Conditions for productive small groups. Review of Educational Research, 64(1), 1-35.

[12] Dobao, A. F., \& Blum, A. (2013). Collaborative writing in pairs and small groups: Learners' attitudes and perceptions. System, 41(2), $365-378$.

[13] Duncan, M. (2007). Whatever happened to the paragraph? College English, 69(5), 470-495.

[14] Eagly, A., \& Chaiken, S. (1998). Attitude structure. Handbook of Social Psychology, 1, 269-322.

[15] Eagly, A. H., \& Chaiken, S. (1993). The psychology of attitudes. Harcourt brace Jovanovich college publishers.

[16] Fachrurrazy, M. A. (2011). Teaching English as foreign language for teacher in Indonesia. Malang: State University of Malang.

[17] Gokce, I. (2001). Effects of Collaborative Writing on Attitudes of Learners Towards Writing At Anadolu University Preparatory School (Issue July).

[18] Hinkel, E. (2011). Handbook of research in second language teaching and learning. Routledge.

[19] Ismail, A., \& Lustyantie, N. (2020). EFL Students' and Lecturer's Perceptions on Collaborative Writing. 2012, 83-95.

[20] Ives, C., Pringle, M., McCloud-Bondoc, L., \& Bosse, C. (2011). Assignment Design for Effective Writing.

[21] Jacobs, H. L. (1981). Testing ESL Composition: A Practical Approach. English Composition Program. ERIC.

[22] Kim, J. K. (2020). The Effects of Collaborative Writing Activity on EFL Learners' Writing Ability. The Korean Association of General Education, 14(2), 131-145.

[23] Krech, D., \& Crutchfield, R. S. (1948). Theory and problems of social psychology. New York: McGraw-Hill.

[24] Letters, Faculty O. F., and Board O. F. Examiners. 2016. "The Impact of Collaborative Writing on Developing Students' Writing Proficiency." (June 2017). 
DOI: $10.51386 / 25815946 /$ ijsms-v4i4p117

Volume: 4 Issue: 4

July to August 2021

https://www.ijsmsjournal.org

[25] Liang, M. Y. (2010). Using synchronous online peer response groups in EFL writing: Revision-related discourse. Language Learning and Technology, 14(1), 45-64.

[26] Lichtman, M. (2013). Qualitative research for the social sciences. SAGE publications.

[27] Lowry, P. B., Curtis, A., \& Lowry, M. R. (2004). Building a taxonomy and nomenclature of collaborative writing to improve interdisciplinary research and practice. The Journal of Business Communication (1973), 41(1), 66-99.

[28] Mulligan, C., \& Garofalo, R. (2011). A collaborative writing approach: Methodology and student assessment. The Language Teacher, $35(3), 5-10$.

[29] Sapkota, A. (2013). Developing Students' Writing Skill through Peer and Teacher Correction: An Action Research. Journal of NELTA, $17(1-2), 70-82$.

[30] Schwarz, N., \& Bohner, G. (2001). The construction of attitudes. Blackwell Handbook of Social Psychology: Intraindividual Processes, 1, 436-457.

[31] Shehadeh, A. (2011). Effects and student perceptions of collaborative writing in L2. Journal of Second Language Writing, 20(4), 286305.

[32] Storch, N. (2005). Collaborative writing: Product, process, and students' reflections. Journal of Second Language Writing, 14(3), 153173.

[33] Storch, N. (2011). Collaborative writing in L2 contexts: Processes, outcomes, and future directions. Annual Review of Applied Linguistics, $31,275-288$.

[34] Storch, N. (2013). 3. Collaborative Writing: L2 Learning and Practice Opportunities. In Collaborative Writing in L2 Classrooms (pp. 2743). Multilingual Matters.

[35] Studies, L., International, A., \& Centre, A. (2015). Languaging and Writing Skill: The Effect of Collaborative Writing on EFL Students' Writing Performance. Advances in Language and Literary Studies, 6(1).

[36] Uusen, A. (2006). Writing Skills of 1st and 2nd Stage Students. Citeseer.

[37] Weigle, S. C. (2002). Assessing writing. Cambridge University Press. 